Brit. J. vener. Dis. (1966), 42, 48.

\title{
RECENT TRENDS IN HOMOSEXUALITY IN WEST LONDON*
}

BY

\author{
J. L. FLUKER \\ Charing Cross Hospital Group
}

Only recently has the problem of venereal disease in homosexuals reached serious proportions in Great Britain, and above all in London. Because these people must be treated and nothing done to discourage their attendance, the personal attitude of the medical and nursing staff is of paramount importance. When on Merseyside, I was impressed by the obvious predilection of these patients for certain doctors and clinics. Apart from downright unpleasantness, nothing is more likely to discourage attendance than either barely-concealed disgust or a well-meant sermon.

Since April, 1963, a strenuous effort has been made to encourage these patients to attend the West London Hospital. From 1959 to 1962 the new homosexual cases varied between 2.5 and 3.5 per cent. of all new male cases, but this has now risen to $9 \cdot 2$ per cent. (Table I). The proportion of active homosexuals has increased significantly, and this is no doubt partly due to less reluctance in disclosing the source of infection. The most serious rise has occurred in the numbers of those with early syphilis,

* Received for publication June 9, 1965. the incidence of which has nearly trebled during the past 6 months (Table II).

Out of the 1964 total there were only seven coloured patients: one with secondary syphilis and a rectal chancre, three with urethral gonorrhoea, two with non-gonococcal urethritis, and one with rectal warts. In the first months of 1965 there were six: a married man with an anal chancre who also had lymphogranuloma venereum, one with secondary syphilis, one with urethral and another with rectal gonorrhoea, and two with minor conditions. Only four of these thirteen men came from the Caribbean.

Of particular patients with syphilis, five with rectal chancres were married, and of these four in the secondary stage had infected their wives. Another man with both secondary syphilis and rectal gonorrhoea actually got married on the day following his first consultation. Yet another with two heterosexual and five homosexual contacts had acquired his first infection from one of the former.

All this does not mean that the physician's sole duty is the cure of the patient's infection. In the great majority of cases, once his confidence has been gained, the patient is given the opportunity to talk

TABle I

INCIDENCE OF HOMOSEXUAL CASES AT WEST LONDON LUKE CLINIC

\begin{tabular}{|c|c|c|c|c|c|c|c|c|c|}
\hline \multirow{3}{*}{ Year } & \multirow{3}{*}{$\begin{array}{c}\text { Total } \\
\begin{array}{c}\text { Homosexual } \\
\text { Patients }\end{array}\end{array}$} & \multirow{3}{*}{$\begin{array}{c}\text { Total } \\
\text { Patients }\end{array}$} & \multicolumn{6}{|c|}{ Homosexual Cases } & \multirow{3}{*}{$\begin{array}{l}\text { Total } \\
\text { Cases }\end{array}$} \\
\hline & & & \multicolumn{2}{|c|}{ Active } & \multicolumn{2}{|c|}{ Passive } & \multirow{2}{*}{ Total } & \multirow{2}{*}{$\begin{array}{c}\text { Percentage } \\
\text { of Total } \\
\text { Cases }\end{array}$} & \\
\hline & & & No. & Per cent. & No. & Per cent. & & & \\
\hline $\begin{array}{c}1962 \\
1963 \\
1964 \\
\text { Jan. to } \\
\text { Apr., } 1965\end{array}$ & $\begin{array}{l}- \\
320 \\
121\end{array}$ & $\begin{array}{l}\overline{-} \\
3,645 \\
1,330\end{array}$ & $\begin{array}{r}30 \\
33 \\
168 \\
52\end{array}$ & $\begin{array}{l}25 \cdot 9 \\
16 \cdot 6 \\
48 \cdot 4 \\
40 \cdot 3\end{array}$ & $\begin{array}{r}86 \\
159 \\
181 \\
77\end{array}$ & $\begin{array}{l}74 \cdot 1 \\
83 \cdot 4 \\
51 \cdot 6 \\
59 \cdot 7\end{array}$ & $\begin{array}{l}116 \\
199 \\
347 \\
129\end{array}$ & $\begin{array}{l}3 \cdot 4 \\
4 \cdot 9 \\
8 \cdot 4 \\
9 \cdot 2\end{array}$ & $\begin{array}{l}3,369 \\
4,066 \\
4,145 \\
1,400\end{array}$ \\
\hline
\end{tabular}

TABLE II

INCIDENCE OF HOMOSEXUALITY IN MAIN CATEGORIES OF DISEASE

\begin{tabular}{|c|c|c|c|c|c|c|c|c|c|c|c|c|c|c|c|}
\hline \multirow{3}{*}{ Year } & \multicolumn{5}{|c|}{ Early Syphilis } & \multicolumn{5}{|c|}{ Gonorrhoea } & \multicolumn{5}{|c|}{ Other Diseases } \\
\hline & \multicolumn{4}{|c|}{ Homosexuals } & \multirow[b]{2}{*}{$\underset{\text { Cases }}{\text { All }}$} & \multicolumn{4}{|c|}{ Homosexuals } & \multirow[b]{2}{*}{$\begin{array}{c}\text { All } \\
\text { Cases }\end{array}$} & \multicolumn{4}{|c|}{ Homosexuals } & \multirow[b]{2}{*}{$\begin{array}{c}\text { All } \\
\text { Cases }\end{array}$} \\
\hline & Active & Passive & Total & $\begin{array}{c}\text { Per } \\
\text { cent } \\
\text { of } \\
\text { Total }\end{array}$ & & Active & Passive & Total & $\begin{array}{c}\text { Per } \\
\text { cent. } \\
\text { of } \\
\text { Total }\end{array}$ & & Active & Passive & Total & $\begin{array}{c}\text { Per } \\
\text { cent. } \\
\text { of } \\
\text { Total }\end{array}$ & \\
\hline $\begin{array}{c}1962 \\
1963 \\
1964 \\
\text { Jan. to } \\
\text { Apr., 1965 }\end{array}$ & $\begin{array}{r}1 \\
3 \\
10 \\
18\end{array}$ & $\begin{array}{r}4 \\
9 \\
25 \\
12\end{array}$ & $\begin{array}{r}5 \\
12 \\
35 \\
30\end{array}$ & $\begin{array}{l}11 \cdot 1 \\
19 \cdot 0 \\
38 \cdot 0 \\
73 \cdot 2\end{array}$ & $\begin{array}{l}45 \\
63 \\
92 \\
41\end{array}$ & $\begin{array}{l}18 \\
20 \\
88 \\
20\end{array}$ & $\begin{array}{l}50 \\
79 \\
86 \\
40\end{array}$ & $\begin{array}{r}68 \\
99 \\
172 \\
60\end{array}$ & $\begin{array}{r}6 \cdot 9 \\
8 \cdot 7 \\
15 \cdot 5 \\
19 \cdot 3\end{array}$ & $\begin{array}{r}989 \\
1,140 \\
1,107 \\
311\end{array}$ & $\begin{array}{l}15 \\
10 \\
70 \\
14\end{array}$ & $\begin{array}{l}17 \\
71 \\
70 \\
25\end{array}$ & $\begin{array}{r}32 \\
81 \\
140 \\
39\end{array}$ & $\begin{array}{l}1 \cdot 4 \\
2 \cdot 8 \\
4 \cdot 9 \\
3 \cdot 7\end{array}$ & $\begin{array}{l}2,297 \\
2,863 \\
2,846 \\
1,048\end{array}$ \\
\hline
\end{tabular}


about his deviation objectively. Discussion is never pressed on an unwilling patient, but the majority are only too glad of such a chance of better adjusting themselves to their environment. Very few have the slightest wish to be changed, and despite past psychiatric help, many have given up the unequal struggle. Many, even under the age of 25 , have a pathological aversion, amounting at times to fear, of the opposite sex and would not even contemplate psychiatric treatment. The most extreme example was seen in a patient with secondary syphilis and a striking palmar syphilide who, while more than agreeable to unrestricted examination by male medical students, refused to expose even one hand to any feminine gaze.

During 1964 only ten patients agreed to seek psychiatric advice out of approximately 200 to whom it was offered and only one asked for it of his own accord. Of these, four cancelled their appointments. Three of the remainder, aged 20, 25, and 31 respectively, are making good progress and the youngest is engaged to be married. A fourth, who was impotent with the opposite sex on account of homosexual tendencies, is much improved in both respects.

Two men, whose psychiatric appointments were delayed for 3 months, were effectively dealt with by us. One of these, who was aged 24 , was deserted overnight by his sexual partner of 4 years' standing and was left with a legacy of secondary syphilis and a personality disturbance which unfitted him for work. Both complaints were treated successfully though subsequently the psychiatrist adjudged the homosexuality incurable. The second, who was aged 35, had rectal gonorrhoea acquired in Amsterdam following excessive alcohol after a business meeting. He was engaged to be married and, although this was his first overt homosexual experience, it had increased his anxiety over the latent tendencies that he had always recognized within himself. It so happened that he found proctoscopy highly distasteful and as he also had an infection that was highly insensitive to penicillin and to other remedies, the unusually prolonged treatment thoroughly upset him but acted as an effective aversion therapy. $\mathrm{He}$ is now stated to be completely cured of homosexuality both by himself and by the psychiatrist.

One other case merits a mention, a married man aged 38 who was referred with rectal gonorrhoea; owing to impotence his marriage was childless but after treatment from within the department this disability was overcome and a family started.

Despite these occasional successes, the overall results are disappointing, but our staffing ratio is meagre compared with that of most clinics of similar size where the results may therefore be better. Homosexuality is undoubtedly widespread and productive of much social and individual misery. Its present association with a high rate of venereal disease is almost completely unknown to the general public. Quite apart from the publicity focused on the recommendations of the Wolfenden Report to which it is hoped that legal effect may soon be given, an educational campaign on the risks of venereal disease associated with homosexual practices is surely overdue. Reliance upon the general press publicizing a leading article in the Lancet-or any other article on the subject-is clearly inadequate. Even more important, though perhaps beyond our present scope, is the need for education of the public on the causes and prevention of homosexuality, and in this the medical profession should surely play an important part.

\section{Summary}

Different methods of approach to homosexual patients with venereal diseases are noted, and the results are described of a deliberate attempt to encourage their attendance over a 2-year period. Endeavours to obtain psychiatric treatment had only poor results and a plea is entered for public health education on the subject.

\section{REFERENCE}

Extract from Annual Report of the Chief Medical Officer to the Ministry of Health for 1963. (1965). Brit. J. vener. Dis., 41, 45.

Les récents développements à propos de l'homosexualité dans l'ouest de Londres

\section{RÉSUMÉ}

Les différentes méthodes d'approcher les pédérastes atteints de maladies vénériennes ont été notées ainsi que les résultats obtenus après un effort prémédité pour encourager leurs visites à l'hôpital pendant deux ans. Les tentatives faites pour obtenir un traitement psychiatrique ont obtenu un maigre résultat et un appel est fait au service d'hygiène publique de pourvoir à l'instruction des pédérastes. 